\title{
An Islamic Model of Conflict Management and Conflict Resolution: Lahad Datu in Sabah as a Case Study
}

\author{
Ahmed Abdul Malik* \\ Muhammad Khairi Bin Mahyuddin \\ Najib Sheikh Abdisamad \\ Mikail Ibrahim \\ Islamic Science University of Malaysia (USIM), \\ Nilai, Negeri Sembilan, Malaysia \\ ${ }^{*}$ Corresponding Author
}

Doi: 10.2478/mjss-2018-0056

\begin{abstract}
Conflict is an inevitable part of human life. In any situation involving more than one person, conflict can arise. The causes of conflict range from philosophical differences and divergent goals, to power imbalances. When conflict arises, it is easy for people to be stubborn and remain entrenched in their positions and for tempers to flare, voices to rise and body language to become defensive or aggressive. Conflict is an unexpected inconvenience. This can be proved by the Lahad Datu Sabah conflict which occurred in 2013, where armed men landed in Lahad Datu to enforce an ancestral land claim. During the conflict, 12 security police were killed and some of them were mutilated. A week-long impasse in a coastal village ended in bloodshed, as a Malaysian ground assault gave way to air strikes. The aims of this research is to analyze the issues of Lahad Datu, to examine the strategies that can be used to promote peace and stability and to introduce an Islamic model of conflict resolution. A self-constructed survey instrument was distributed to 236 residents of Lahad Datu, who voluntarily participated in the study. The results indicated that a level of awareness and a resolution of conflict effects peoples' reaction towards a government's response to invaders, their perceptions about the causes of the conflict and their stance during a conflict. Furthermore, the study found that gender, religion, education, occupation and marital status had no effect on the dependent variables. Finally, the findings of the research disclosed that an Islamic model of conflict resolution can be used to resolve the conflict of Lahad Datu or similar social conflicts.
\end{abstract}

Keywords: Islamic model, conflict management, Lahad Datu, conflict resolution, Sabah

\section{Introduction}

Internal conflicts can be detrimental to the peaceful co-existence of a nation or a very wellorganized institution. Nowadays, having the skills to resolve internal conflicts effectively is one of the biggest challenges and is vital to success. Jones (2014) conducted a report on communal and ethnic violence in the Southeast Asian region, especially in Indonesia, Philippines and Myanmar. He mentioned in his report that in the conflict in Malacca for the past two years, about 4,000 people have been killed in Christian-Muslim fighting, and about 500,000 displaced, according to Indonesian Red Cross figures. That is clearly the worst of the conflicts we are facing right now, but even though it is considered religious issues as arising from some long-seated religious dispute. Truth be told, 
there are actually a lot of historical, political and economic factors that lie at the root of the conflict. There is also conflict in west Kalimantan, which is now somewhat quiescent. Nevertheless, in 1999, it broke out again with hundreds of people being killed. There was a previous episode of conflict in 1997 which produced large-scale deaths. The conflict was largely between indigenous Dayaks and some indigenous Malays against the immigrant Madurese group. This issue of migrants against indigenous people is a major theme that runs through communal conflict in Indonesia.

In Philippines, the conflict between the Muslim Independence Movement (MIM), which is considered to originate from the Moro National Liberation Front (MNLF) and the Filipino government has lasted for nearly half a century and has caused many spiritual and material losses. Unfortunately, the civil war and religious conflict in Philippines continues to date despite the intervention of international bodies and humanitarian institutions to end the crisis.

In Myanmar, thousands of Rohingya have been killed due to differences in race, religion and ethnicity. The Government of Myanmar does not even recognize the existence of human rights violations in its own country. Instead, it considers the existing crises as a necessary norm and supports legal action to purge the country from those who do not have the legitimate right to exist in Myanmar. Despite the fact that Malaysia is relatively different from Indonesia in the sense that it is peaceful and helpful to Nusantara and non-Nusantara nationals, nevertheless, conflict does exist. This can be proved by the conflict of Lahad Datu Sabah on 2013, which was initiated by Sultan Jamalul Kiram III from the Philippines. On February 6, 2013, gunmen who claimed to be supporters of Sultan Jamalul Kiram III attacked Lahad Datu to reclaim the land of their ancestors. Around 200 of Jamalul Kiram's followers, some of heavily armed, were dispatched to Sabah. They killed 12 security police and some of them were mutilated. The Malaysian armed forces resisted this attack, killing many of the assailants and arrested their supporters.

According to Paul Pryce (2013), the actions of the rebels 'Royal Army of Sulu', constitute as a threat to Malaysian sovereignty over the Sabah region, though reports have suggested that the Malaysian security forces largely prevailed within the first few days of open hostilities. It is vital to the long-term viability of the ASEAN Political-Security community, however, that the challenges presented by the Sabah conflict are not quickly forgotten.

Conflict happens in any place and during any situation, when two or more parties disagree each other. It is clear that conflict is unavoidable between humankind. However, it is most important to know how to cope with it, the way out and effective conflict management and resolution strategies. Allāh has mentioned that there will always be a way out if two parties want it. Indeed, he said, "If they both wish for peace, Allāh will cause their reconciliation. Indeed, Allāh is Ever AllKnower, Well-Acquainted with all things" (Qur'ān 4:35).

The present research aimed to investigate and analyse aspects of Islām which deals with peace, conflict resolution and conflict management in a society or a nation. Moreover, this paper discusses Islamic models of conflict resolution and conflict management.

\section{Statement of the Problem}

Conflict may occur for many reasons. Nevertheless, in the case of the Sabah Conflict (2013), the problem was about the loss of ancestral land of the Tausugs due to a deception started by the British and perpetrated by the Malaysian government. Due to the loss of their ancestral land, the Muslims in south Philippines felt they had been marginalized when the Malaysians were enjoying the bountiful benefits of the Tausugs' ancestral territory.

There a lot of provocateurs that added fuel to the conflict through social media, among them was Vidal Yudin Weil (2014) who wrote in his article that "this article is intended for those who think Malaysia or rather Malaya owns Sabah and Sarawak". Despite the fact that Vidal Yudin Weil (2014) had extensive writing skills and experience in dealing with the press, it was challenging for him to write a fair statement on the Malaysia and East Malaysia (Sabah and Sarawak) issue.

Another active provocateur was Luke Hunt (2014) who said: "More than 70 soldiers were killed by Malaysian forces, while the rest melted in with the ethnic Filipino locals and refugees who controlled the surrounding water villages, raising fears that the insurgency could again turn bloody on the sultan's orders". 
It was also stated in a Sabah Conflict special report in 2014 that if the Sabah issue did not have closure, it would drain the resources of Malaysia over the long term. Furthermore, it was also mentioned that: "Sabah is still really ours. However, it is not easy to resolve this conflict, especially with armed struggle".

There are more than 900,000 Tausug people living in Sabah. But there are thousands of other people from the Philippines that are living in Sabah, some with legal documents and some without any documents at all. There are even people that believe in Sulu sultanate in Sabah who have similar opinions to the provocateurs mentioned above. The conflict is a problem that the researchers believe can be resolved by an Islamic model of conflict management and conflict resolution. As such, this study aimed to analyze the historical background of Lahad Datu from an Islamic perspective, and examine the strategies that could be used to promote peace and stability in Lahad Datu. Furthermore, it aimed to introduce appropriate Islamic models to promote peace and stability in Lahad Datu. Therefore, this study attempts to answer the following questions:

1. What is the historical background of the conflict in Lahad Datu, from an Islamic perspective?

2. What are the strategies that can be used to terminate the conflict in Lahad Datu?

3. What are the Islamic models of promoting peace and stability in Lahad Datu?

\section{Methodology}

\subsection{Participants}

A number of 236 (males $=47.5 \%$, females $=52.3$ ) residents of Lahad Datu were selected to voluntarily participate in the study. The ages of the participants ranged between 18 and 55 years old. The participants were residents of Lahad Datu who witnessed the conflict from invasion to intervention of the authorities to resolve the situation. The participants were informed of the aims of the study who then eagerly expressed their willingness to participate in the study. It is worth mentioning that Lahad Datu consists of a population estimated to be around 199,830 in 2010. Lahad Datu is a small remote town located in the eastern part of Sabah, Malaysia. "There are over 100,000 people living in this area with a majority of Malay, Chinese and other ethnic groups. However, in early 2013, Lahad Datu became a site of standoffs between Malaysian security forces and suspected members of a known rebel group" (Erman Anom et al., 2014).

\subsection{Instrumentation}

A self-reported instrument was constructed and used to carry out this study. The questionnaire initially consisted of 60 items, with 5 demographic variables. It was then categorized into five categories; namely, level of awareness, perception about the Malaysian government's reaction, causes of the Lahad Datu conflict, stance of the people during the conflict and resolution of the Lahad Datu conflict. Each of the subscales consisted of 10 items. However, after consultation with conflict resolution experts, some items were dropped due to the lack of face validity. Moreover, the researchers also tested the internal consistency of the scale via the use of Cronbach's alpha. The reliability values of the scale were $.827, .719,878, .745$ and .770 for awareness, reaction, causes of the conflict, stance of the people and resolution of the conflict respectively.

The survey responses were measured using a Likert-style scale. The scale was rated between one to five $(1-5)$ and the adjacency between the intervals was assumed to be equal. The scales were classified as strongly disagree (SDA), disagree (DA), strongly agree (SA), agree (A), and neutral (NC). The survey also consisted of short demographic variables which requested information regarding gender, age, marital status, occupation, religion and education. Each item of the questionnaire asked the respondents how strongly they agreed or disagreed with the statements.

As has been previously highlighted, the researchers examined the internal consistency of the questionnaires by using Cronbach's alpha. The Cronbach alpha for each question in the test ranged between .708 to .890 . The internal consistency examination suggested that the items 
perfectly measured what they purported to measure. The high internal consistency value suggested that the items perfectly targeted the respondents and that the respondents sincerely responded to the questionnaire. It is worth mentioning that 12 items were discarded from subsequent analysis after there were comments from the experts on their ambiguity and lack of internal consistency.

\subsection{Test of assumption}

In order to meaningfully employ the Multivariate Analysis of Variance (MANOVA) tool, some fundamental assumptions were required to be fulfilled. The assumptions were normality, linearity, test of multicollinearity, outliers and data screening. According to Hair et al. (2010), the most fundamental assumption in multivariate analysis is normality. They referred to the shape of the data distribution for an individual variable and its normal distribution. Thus, the examination of normality assumption via skewness and kurtosis values suggested that assumption held since the values below the cut-off of +2.0 as suggested by practitioners (Kline, 1998; Hair, et al. 2010; Bryne, 2010). Moreover, the linearity assumption was also tested by an examination of the cordial relationship between certain factors.

The linearity assumption showed a straight-line relationship between two variables. This assumption was very important because multivariate analyses would only capture a linear relationship between factors (Tabachnick \& Fidell, 2001). According to Schumacker and Lomax (1996), the extent to which one or both variables deviate from the assumption of a linear relationship affects the size of the correlation coefficient. The researchers conducted a series of multiple regressions using a studentized (SRED) residual pilot against each of the predicted dependent variables to examine the linearity between them. A visual inspection of the residual plots illustrated that the scores were scattered randomly with no distinct pattern, thus suggesting that the assumption was reasonably met. Finally, a lack of evidence of serious violations of the assumptions provided a justification for the researchers to continue with the analysis (Tabachnick \& Fidell, 2001).

In relation to multicollinearity, the researchers also assessed the correlation between the independent variables of this study to determine the appropriateness of the data. Multicollinearity, according to Pallant, 2013, exists when independent variables are highly correlated $(r=0.9$ and above). Although, correlation between variables is fundamental in any multivariate analysis, nevertheless, the correlation among the independent variables should be minimized in order to avoid the problem of multicollinearity. The existence of multicollinearity will negatively affect the internal validity of multivariate analyses (Field, 2009; O'brien, 2007). The researchers examined the assumption of collinearity by conducting a multiple regression analysis and examined a VIF and Tolerance. The results of both analysis indicated a lack of multicollinearity since the values of the VIF were below 10 and Tolerance was below 1.0. Additionally, the data was screened to ensure that it transcribed efficiently by looking at inconsistent responses and checked for missing data and outliers. Missing data with less than 5 was replaced by its respective mean value, whereas data which had more than 5 missing values and outliers were removed from the data set. Therefore, it can be concluded based on the results of the assumptions that the data was suitable for multivariate analyses.

Table 1: Test for multicollinearity

\begin{tabular}{lcc}
\hline Factor & Tolerance & VIF \\
\hline Level of awareness & .770 & 1.66 \\
Perceptions about the Malaysian Government's Reaction & .789 & 1.97 \\
Relation between conflict and Patriotism & .975 & 2.49 \\
Causes of the Lahad Datu conflict & .777 & 1.80 \\
Stance of the people during the conflict & .790 & 1.55 \\
Resolution of the Lahad Datu conflict & .866 & 2.50 \\
\hline
\end{tabular}




\section{Results of Manova}

The first step in a Multivariate analysis is to test the assumption of equality of the variances and normality of the data. Nevertheless, since the normality assumption was tested before the analysis of MANOVA, the researchers did not perform the test again. Instead, Levene's test was checked for further assumptions. Levene's test revealed the insignificance of the test, $p>.05$. This insignificance of the test indicated that a null hypothesis of equal variances was maintained.

Table 2: Levene's test of equality of error variances

\begin{tabular}{lcccc}
\hline Variables & $\boldsymbol{F}$ & $\boldsymbol{d f ^ { \prime }}$ & $\boldsymbol{d f}^{\mathbf{2}^{\mathbf{2}}}$ & Sig \\
\hline Level of awareness & 2.304 & 3 & 47 & .089 \\
Reaction of the Malaysian Government & .377 & 3 & 47 & .770 \\
Relation between Conflict and Patriotism & 2.684 & 3 & 47 & .057 \\
Causes of conflict & .503 & 3 & 47 & .682 \\
Stance of people & 1.518 & 3 & 47 & .222 \\
Resolution & 2.187 & 3 & 47 & .102 \\
\hline
\end{tabular}

It is obvious from the above table that all factors were statistically insignificant, which indicated that a null hypothesis of the equal variances was maintained.

The factorial MANOVA table is presented in Table 3. The results of the analysis revealed that there was an overall significant multivariate of the model with regards to level of awareness (Hotelling's $t=2.199, F 5.773, p=.001$ ), and resolution of conflict (Hotelling's $t=.664, F 3.321, p=$ .005). However, the study also found that the overall multivariate for gender was Hotelling's $t=$ $.245, F$ 1.226, $p=.309$, religion, Hotelling's $t=.334, F$.991, $p=.511$, education, Hotelling's $t=$ .421, $F .725, p=.444$, occupation, Hotelling's $t=.302, F .203, p=.490$, marital status, Hotelling's $t$ $=1.01, F .661, p=.399$ and interaction effects Hotelling's $t=.231, F 1.157, p=.349$, were statistically insignificant, . The results indicated that, generally, the model was statistically significant and that level of awareness, and conflict resolution played a role on the reaction of the people to the government's reaction, perception of the relationship between conflict, patriotism and the stance of people during the time of conflict. On the other hand, the analysis found that gender, religion, education, marital status and interaction effects were statistically insignificant.

Table 3: Summary of factorial MANOVA of conflict management and conflict resolution

\begin{tabular}{lccc}
\hline Variables & Hotelling's $t$ & $F$ & $p$ \\
\hline Intercept & 208.673 & 1043.363 & .001 \\
Awareness & 2.199 & 5.773 & .001 \\
Resolution & .664 & 3.321 & .005 \\
Gender & .231 & 1.157 & .349 \\
Religion & 334 & .991 & .511 \\
Education & .421 & .725 & .444 \\
Occupation & .302 & .490 & .490 \\
Marital status & 1.01 & .661 & .399 \\
\hline
\end{tabular}

Based on the results of MANOVA, tests on between-subject effects (Univariate) were examined. The univariate results revealed that there was an overall effect (Univariate) of level of awareness and resolution, on reactions to the Malaysian government $F(1,47)=5.128 p=.001$, MSE $=.294$, the relation between Conflict and Patriotism $F(1,47)=5.771 p=.001$, MSE $=.138$ and stance of people during conflict $F(1,47)=6.210 p=.001$, MSE $=.138$. Moreover, the analysis also suggested that level of awareness was solely correlated with the reaction of the government, $F(1$, $47)=18.072, p=.001, \mathrm{MSE}=.211$, relation between conflict and patriotism, $F(1,47) 15.455, p=$ .001 , MSE $=.170$, and stance of people during a time of conflict, $F(1,47) 12.839, p=.001$, MSE $=$ .139. Furthermore, the analysis also suggested that resolution was also significantly related to the reaction of the Malaysian government, $F(1,47) 13.599, p=.001$, MSE $=.208$, relations between Conflict and Patriotism $F(1,47), 6.819, p=.012, \mathrm{MSE}=.179$ and stance of people during the conflict $F(1,47), 16.548, p=.001$, MSE $=.139$. However, the analysis also found that interaction 
effects between level of awareness and resolution were statistically insignificant. According to the results, the interaction effects for reaction of the Malaysian government, $F(1,4)=2.936, p=.201$, relation between conflict and patriotism, $F(1,4)=.291, p=.868$, and stance of people, $F(1,4)=$ $.162, p=.942$, were statistically insignificant. Table 4 provides further detail below.

Table 4: Results of the ANOVA of conflict management and conflict resolution

\begin{tabular}{|c|c|c|c|c|c|c|}
\hline Source of var & & Sum of Squa & DF & ean Square & $F$ & $p$ \\
\hline Main effects & Reaction of the Malaysian Government & 607.332 & 47 & 607.332 & 5.128 & .001 \\
\hline & Relation between Conflict and Patriotism & 780.903 & 47 & 780.903 & 5.771 & .001 \\
\hline & Stance of people & 827.783 & 47 & 827.783 & 6.210 & .001 \\
\hline Awareness & Reaction of the Malaysian Government & 71.661 & 47 & 33.330 & 18.072 & .001 \\
\hline & Relation between Conflict and Patriotism & 66.156 & 47 & 29.231 & 15.455 & .001 \\
\hline & Stance of people & 80.809 & 47 & 31.809 & 12.839 & .001 \\
\hline Resolution & Reaction of the Malaysian Government & 55.783 & 47 & 26.783 & 13.599 & .001 \\
\hline & Relation between Conflict and Patriotism & 48.003 & 47 & 19.102 & 6.819 & .001 \\
\hline & Stance of people & 37.901 & 47 & 23.244 & 16.548 & .001 \\
\hline Interaction & Reaction of the Malaysian Government & .391 & 4 & 005 & 2.936 & .201 \\
\hline & Relation between Conflict and Patriotism & 194 & 4 & .057 & .291 & .868 \\
\hline & Stance of people & 379 & 4 & .007 & 162 & .942 \\
\hline
\end{tabular}

\section{Discussion}

The MANOVA analysis revealed that level of awareness of the Sulu Sultanate, the Lahad Datu incident and resolution of Lahad Datu conflict significantly contributed to the responses of people towards the Malaysian government's reaction to the intruders, causes of the conflict and stance of people during the conflict. The results indicated that level of awareness and resolution of conflict affected the support of people towards the government's response to invaders, their perceptions about the causes of the conflict and their stance during the conflict. However, the study also found that gender, religion, education, occupation and marital status had no effect on dependent variables.

These findings were inconsistent with previous studies. According to Logan Ma (March 15, 2013), despite the fact that the Filipino government has made claims to the region, the Filipino President, Benigo Aquino, has cooperated with the Malaysian government. Aquino's unwillingness to confront the Malaysian authorities can be attributed to two factors. Firstly, Malaysia recently helped broker a peace agreement last November between the Filipino government and the Moro Islamic Liberation Front (MILF), which was one of the groups involved in the Moro Muslim insurgency in Mindanao. Ironically, the conflict began in 1967, after Filipino soldiers massacred Moro fighters preparing to invade Sabah. Secondly, any perceived effort to pursue Filipino claims on the region places them under heightened security in Sabah and would threaten the estimated 800,000 Filipinos living there, many who are refugees of the Mindanao conflict. It is necessary to mention that Logan Ma did not touch on solutions for the conflict or even suggest a kind of resolution that may contribute to the issue between the Malaysian and the Filipino government.

Erman Anom, Chang Peng Kee and Julia Wirza Mohd Zawawi (2014) also studied the issue of Sabah from a political point of view and considered the Sabah conflict as an issue that was related to Malaysia. They believed it was paramount for the issue to be resolved in order to stabilize security, political and economic relations between Southeast Asian countries.

The writers highlighted the importance of relations and cooperation between the countries of the world in general and Southeast Asian countries in particular. This cooperation was necessary for the progress and development of the countries in the region and the welfare of their people.

They also stressed on the importance of peace and stability in a region, as they viewed treaties between nations as normal and well accepted politically and socially. Furthermore, they believed that South East Asia had the potential to overcome crises, difficulties and could strive to progress and prosper.

The authors drew upon tremendous knowledge of the issue and provided original and significant advances in the general area of political methodology, including both quantitative and qualitative methodological approaches.

There have been many empirical studies that have examined the conditions of the area and 
have offered useful suggestions and recommendations. One of the studies mentioned that Lahad Datu was the location where oil palms were extensively farmed in Sabah. Their analyses provided insight into a more detailed impact that land cover changes are having on Lahad Datu, and the ways in which such changes are creating or constraining opportunities for the expansion of perennial cellulosic feedstocks. (Nur Shafawati Saili et al., June 20, 2014).

Their research focused more on the natural sites of Sabah and Lahad Datu. Indeed, there is no doubt that Sabah is one of the most beautiful states in Malaysia, and this due to its unique and beautiful flora and fauna. Sabah is known for its beauty and splendour, and the diversity of its geographic regions. It has high mountains, forestry and wild animals. In addition to this, there are large numbers of lakes, rivers and coastal beaches.

It is important to mention that Mount Kinabalu in Sabah is one of the most famous mountains in the world. It has been awarded as one of the world's first UNESCO World Heritage Sites. The mountain is about 4095 meters above sea level and there are many wild animals, giant plants and beautiful birds on this mountain.

This research is important for the Sabahan and Malaysian government because it ensures the Malaysian government and companies that run their businesses in Lahad Datu and Sabah conserve biodiversity, develop resources for sustainability and share the benefits resulting from their use. Indeed, "under the rules of Malaysia, it is expected that bio-prospecting or the collection of natural products has to be allowed by the biodiversity-rich country, in exchange for a share of the benefits" (Sabah State Government, 2016).

The statement above may have not touched on the conflict of Lahad Datu in Sabah, but it has added significant information regarding the meaning, factors responsible, prevention and control measures of land degradation. It calls for land prevention and maintenance and highlights the huge human advantage over all life on earth. Allāh created the universe very accurately. If we look at the environment with its comprehensive meaning, it can be found that it has received a great deal of attention. Islām has developed the general framework of the law of environmental protection. Allāh Says in the Holy Qur'ān: "and do not mischief on the earth after it has been set in order, that will be better for you, if you are believer" (Qur'ān 7:85).

It is not surprising that the environment is of great interest to Islamic law and Islamic teachings. It is the heritage of generations which Allāh has deposited all the elements of life for man. Therefore, Islām has laid the foundations, rules and principles that regulate the relationship of man to his environment, to achieve a balanced relationship that protects the environment. The role of the environment is determined by the Creator in sustaining life. Allāh says in the Holy Qur'ān: "and do good as Allāh has been good to you, and seek not mischief in the land. Verily Allāh likes not the Mufsidūn (those who commit great crimes, mischief-makers and corrupters" (Qur'ān 28:77).

\section{Recommendations and Suggestions}

This research has provided ideas on how the government can deal with conflict, without the use of weaponry which normally exemplifies the problem and results in the suffering of innocent people. The research suggests that:

1. The government should get to the core of the problem in Lahad Datu i.e. "chunk down" or "chunk up", to gather first-hand information on how to solve the issue and not to rely on uncertain sources and media.

2. There should be no triangulation of the issue from any party. Triangulation of an issue is when one party does not speak directly to another party and involves somebody else or a certain institution from outside.

3. There should be an effort not to politicize the issue by any party. Instead, the issue should be put forward in a clear way so the argument can be understood by two parties during the dialogue process (al-Hiwār).

\section{Conclusion}

The Lahad Datu incident in 2013 was a sign of dissatisfaction, frustration and anger that brewed for many generations resulting from difficulty and poverty. The conflict in Lahad Datu is real, but it can be resolved through an Islamic model of conflict resolution and conflict management. The role of 
the government should be to guide and protect the rule of the law. Furthermore, they should implement the Islamic model in a proper and effective way.

One of the great deeds that Islām has urged and desired, is reconciliation between people. Islām is a religion of love, dialogue, and blessing for all mankind. The Sulu Sultanate and Malaysian government needs an immediate meeting to reconcile the Lahad Datu incident which could result in serious war between parties. This reconciliation is needed because it will be a source of security, stability, love and tranquillity and is a sign of union and solidarity.

\section{References}

Angela E.V. King. (2001). Women and Conflict Management in Africa womenshitory.about.com/ http://www.un.org/events/women/2001/background.htm

Andy Field. (2009). Discovering statistics using SPSS. London: SAGE Publications.

Abdul Aziz \& Nathan C F. (2001). Peace and conflict resolution in Islam, precept and practice. UK. University press.

Barbara G. Tabachnick \& Linda S. Fidell. (2001). Using multivariate statistics. Boston:Allyn and Bacon.

Bernama. (2013). Villagers beat gunman to death. Bernama: Free Malaysia Today. Retrieved 11 October 2013. (freemalaysiatoday.com).

Bryne, (2010). Structural equation modeling with EQS:Basic concepts, applications, and programming. NewYork, NY: John Wiley and Sons.

Borneo Eco Tours. Borneo Eco Tours Travel Advisory. (2017) https://www.borneoecotours.com/travelinfo/advisory.php

Crescent \& Dove, (2011). Peace and Conflict Resolution in Islam. Kuwait: Qamar-Ulhuda.

Erman Anom et al. (2014). Political discourse in Indonesia and Malaysia for national human security: A case study of lahad datu. Malaysian Journal of Communication, 30(2), 183-200.

Elaine Chiao Ling Yang at el., (2015). Tourists' risk perception of risky destinations: The case of Sabah's eastern coast. Sage Journals. March 23, 2015 (http://journals.sagepub.com/doi/abs).

Hair, et al. (2010). Multivariate Data Analysis, (3rd ed.). New York: Macmillan.

Jason Motlagh, (2013). Waging War at the Court of the Sultan of Sulu. http://world.time.com/2013/04/10.

Kline, R. B. (1998). Principles and Practice of Structural Equation Modeling (2nd ed.). New York: Guilford.

Kozan, M. K. (1997). Culture and conflict Management: A theoretical framework. The International Journal of Conflict Management, 8(4), 338-360

Logan Ma. (2013). Malaysian Politics and the Sabah Conflict. PROSPECT. Journal of International Affairs at UCSD, https://prospectjournal.org/2013/03/15/malaysian-politics-and-the-sabah-conflict/

Luke Hunt, (2014) Sultanate Warns Fresh Conflict in Sabah Possible. http://thediplomat.com/2014/01/sultanatewarns-fresh-conflict-in-sabah-possible.

Musa, (2013). Sabahans will not forget Lahad Datu incident —. Bernama: The Borneo Post. 30 June 2013. Retrieved 11 October 2013.

Nur Shafawati Saili et al. (2014). Lignocellulolytic Activities among Trichoderma Isolates from Lahad Datu, Sabah and Deception Island, Antarctic. Journal of Microbial \& Biochemical Technology, 6(5), 295-302

Paul Pryce. (2013). The Sabah Conflict: Grim Vision for ASEAN Security Community? China International Studies, No.39, March/April 2013(http://www.ciis.org.cn.

Pallant, J. (2013). SPSS survival manual: A step by step guide to data analysis using IBM SPSS (4th ed.). Crows Nest, NSW: Allen \& Unwin.

Rahim, M. A. (2002). Toward a theory of managing organizational conflict. The International Journal of Conflict Management, 13(3), 206-235.

Robert M. O'brien, (2007). A Caution Regarding Rules of Thumb for Variance Inflation Factors. https://link.springer.com/article/10.1007/s11135-006-9018-6.

Sabah State Government, (2016). www.sabah.gov.my/cms/?q=en/content/about-sabah.

Shamsul A. B. (2013). No more conflict, but unity remains elusive in Malaysia. http://www.eastasiaforum.org/2013/09/20/no-more-conflict-but-unity-remains-elusive-in-malaysia.

Sidney Jones. (2014). Causes of Conflict in Indonesia. http://asiasociety.org.

The Sabah Conflict, (2013). https://ph.news.yahoo.com/sabah-crisis/

The Star. (2013). Semporna villagers beat to death ex-Moro commander. 3 March 2013. Retrieved 11 October 2013 (thestar.com.my).

Vidal Yudin Weil. (2014). Can Sabah and S'wak secede? freemalaysiatoday.com/category/opinion/2014/04/14 /can-sabah-and-swak-secede.

Vidal Yudin Weil, (2013). Lahad Datu: is there a Solution? http://www.freemalaysiatoday.com/category/opinion /2013/03/06/lahad-datu-is-there-a-solution. 